\title{
Criteria Determining Optimal Portfolio Selection: A Case Study
}

\author{
${ }^{1}$ Diakomihalis Mihail, ${ }^{2} \mathrm{Hyz}$ Alina and ${ }^{3}$ Gikas Grigorios \\ ${ }^{1,3}$ Department of Accounting and Finance, T.E.I. of Epirus, Greece \\ ${ }^{2}$ Department of Accounting and Finance, T.E.I. of Piraeus, Greece
}

Received 2014-02-07; Revised 2014-03-10; Accepted 2014-03-13

\begin{abstract}
The paper examines the evaluation of the significance of the criteria that influence two groups of investors, who reside in different areas of Greece, in selecting their investments: (a) Investors from a metropolitan city (Athens) and (b) investors from regional Greece (Peloponnese). The study is grounded in the current and potential criteria and sub-criteria influencing investors in selecting financial investment products. The methodology applied in order to satisfy the research aims is the Analytic Hierarchy Process (AHP). The quantitative research analysis is based on a sample of data collected via a questionnaire answered by a sample of key experts: Specifically, bank executives specialized in financial investment products. The general conclusions stemming from the comparative study are: Metropolitan city Investors (MIs) are more experienced, more dispassionate, more patient and conservative than the Regional Investors. Furthermore, the MIs are more tolerant, provident and informed. The Regional Investors (RIs) can be perceived as more enthusiastic and interested in taking risks than the MIs, but they also appear to feel less secure when it comes to investing. Future research should address larger number of participants from other metropolitan cities and regions and, eventually, from other countries.
\end{abstract}

Keywords: Investment Portfolio, Analytic Hierarchy Process

\section{INTRODUCTION}

Modern portfolio theory concerns the construction of an investment portfolio. In other words, it refers to the combination of financial products invested and possessed by an investor. Consequently, the portfolio comprises an aggregate of different investments in titles (shares, bonds, mutual funds) and in cash possessed by an individual or a legal entity. The combination of different investments may level out positive and negative returns with the result of reduced unsystematic investment risk. According to this concept, for optimal portfolio selection, the combination of financial products that would incorporate high-expected output and safety, based on the available liquidity of the investor, is anticipated. The following categories of titles that express pecuniary value are included in the financial investments (Rachmawati et al., 2014):
- Shares

- Certificates of deposits

- Bonds

- Bank deposits

- Promissory notes

- New issues of shares

- Call/Put options

\subsection{Elements Contributing to a Successful Portfolio}

Modern portfolio theory originated in the study of Markowitz (1952), who recognized that by combining assets that are not perfectly correlated, an investor could reduce his or her investment risk without reducing expected returns. It is theoretically possible to derive a portfolio of risky assets that returns the smallest amount of risk for a given return (Haugen, 2001; Strong, 1993).

Corresponding Author: Diakomihalis Mihail, Department of Accounting and Finance, T.E.I. of Epirus, Greece 
Diversification plays a very important role in modern portfolio theory. Because a portfolio is a collection of securities, the selection decision is equivalent to selecting an optimal portfolio from a set of possible portfolios.

Apart from the expected appreciation of individual investments, the success of a portfolio is determined by the investment risk that it encompasses. The risks of an investment can be separated into two general categories: The systematic investment risk and unsystematic investment risk (CI, 2011). The nature of these two risks is absolutely different. Systematic investment risk is associated with the market (purchasing power risk, interest rate risk, liquidity risk). The management of systematic risk is exceptionally difficult. It cannot be forecasted, because it results from the macroeconomic environment (legislative changes with impact in the investments, potential martial clash).

On the contrary, unsystematic investment risk is unique to an individual asset (business risk, financial risk, other risks related to investment in a particular asset).

The unsystematic investment risk can be forecasted and eliminated with the process of risk differentiation, in which different forms of investments with different risk are selected in a portfolio. Some important categories of investment risks are presented below (Cooper and Edjett, 2001):

- The business risk concerns all business actions, in which, investments in shares and bonds are included

- The market risk arises from the changes of the prices of certain products either at the national or international level

- The credit risk or default risk is reported in all investments that are realized with transactions that include payments in the future and result from the probability of breach of some future payment that will influence negatively the cash inflows

- The liquidity risk arises from investments that are difficult or impossible to liquidate and in consequence, they can cause lack of cash flow and lead to breach of other agreements of payment

- The interest-rate risk refers to the rise of interest rates that make the investments appear less attractive, since the investors can acquire high return from savings

- The financial risk lies in the investments that include foreign capital and arises from the disability of future obligations settlement

- The inflation risk or purchasing-power risk can affect all the investments but especially those of constant income, such as banking deposits or government bonds

- The exchange-rate risk concerns investments realized in foreign currencies that include the exchange risk, since they can lose part of their value from variation in the exchange parity

- The political risk or country risk refers to the effect of investments on an economy from sudden changes in the current legal framework that has impact on the market

- The systemic risk derives from the collapse of the entire economic system and, even if it is a rare occurrence, can involve devastating consequences to the investments

\subsection{Strategies of Configuration and Management of Portfolios}

The choice of individual investments that will form an investment portfolio is a complicated process determined by the following factors:

- The conditions that prevail in the market

- The personal expectations of the investor (Agwuegbo et al., 2010)

- The type of stocks that are traded in the market (see also: Chen, 2005)

Based on the aforementioned parameters, two strategies exist that determine the configuration of the portfolio: The active and the passive strategies (Burton, 2003).

The choices are usually made according to the characteristics of the investor.

Included in these are the expected return, the time of return, the risk taken by the investor, the profession, the income, the possession of financial assets.

The question is "to what degree do these factors influence the investor when selecting savings-based investments in a portfolio?"

This study aims to answer the above question. For the completion of this research, the Analytic Hierarchy Process (AHP) method was applied.

\section{MATERIALS AND METHODS}

The aim of this study is to present the results of an empirical research to (a) identify the criteria determining the financial products comprising the investment portfolios of private investors in Greece and (b) conclude on the hierarchy that each of these criteria has.The methodology that was used is illustrated in Fig. 1. 


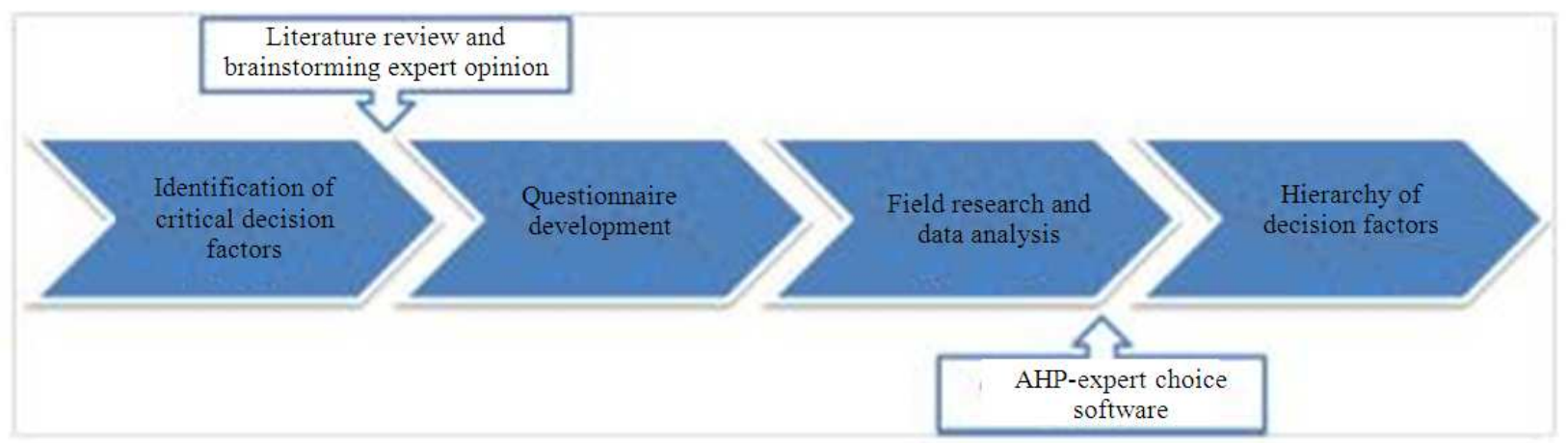

Fig. 1. Methodological framework

More precisely, the first Step was to identify the key parameters that affect the factors that influence the decisions of potential investors concerning the structure of their portfolio and particularly the key parameters that affect their private savings investment. Literature on this specific area is rather scant. Therefore, a brainstorming session was performed, in order to map the total number of factors that could influence this kind of decision.

The next step of the research was the development of a questionnaire based on the findings of the previous Step. The structure of the questionnaire comprises 34 pairwise comparisons on a 9-point Likert type scale. The final stage was the data elaboration and the calculation of the importance of each factor by using the Analytic Hierarchy Process (AHP) (Diakomihalis and Stefanidaki, 2012).

The Analytic Hierarchy Process (AHP) uses hierarchical decision models that have a mathematical basis. AHP is a multi-criteria method developed by Saaty $(1977$; 1980b; 1999) for decision making and priorities ranking. This method combines subjective and objective estimations or perceptions in an integrated framework, which is based on scale ratios from pair comparisons (Saaty, 1980a). The judgments from the pair comparisons are made by experts or decision makers and in combination with the use of the AHP algorithm produce the final outcome. The criteria with which the comparisons are made and the final hierarchy deriving from them, are not necessarily determined. It is possible and acceptable to be based on non-measurable factors such as experience and subjective judgment. After the completion of the process, the most important factors have the highest gravity coefficients (Saaty, 1999; 2005). AHP method has the ability to structure complex, multi-person, multi-attribute and multi-period problem hierarchically. AHP method is useful in solving problems connected with choose of the best solution, especially when the choice of certain solution is based on subjective preferences of examined group (Parlinska and Petrovska, 2011). Pairwise comparisons of the element (usually, alternatives and attributes) can be established using a scale indicating the strength with which one element dominates another with respect to a higher-level element. This scaling process can then be translated into priority weights-scores (Yusuff et al., 2001).

\subsection{Identification of Critical Decision Factors and Questionnaire Development}

The first Step includes the identification of factors that influence the decisions of potential investors concerning the structure of their portfolio and particularly the key parameters that affect their private savings investment. Given the limited research in this area brainstorming was firstly used to identify the broad area of factors that may play an important role in the decision for an investment portfolio. This process was performed with major stakeholders of the Greek investment experts (bank investment consultants) who were asked to confirm or to eliminate the factors which consider as relevant or irrelevant to private savings investment, from a number of listed items. Following discussion with local banking executives the list of the key factors was narrowed to a set of 4 major criteria categories each of which can be further broke down into sub-criteria.

These categories are the following:

- Characteristics of potential investors: Includes all the characteristics of the potential investor such as gender, age, education, marital status and familiarity with technology

- Financial situation of potential investors: Refers to the profession or occupation of the investor, his or her possession of assets and annual income and lastly the forecast for future personal or family income 
The type of investor: Includes his or her investment experience, the time of holding the investment, the psychological reaction in times of negative fluctuations and his or her tolerance of losses during a recession period.

The type of investment: Refers to the purpose of the investment, the level of return fluctuation, the risk the investor is willing to take and the time of return.

The hierarchic structure of the levels of criteria as well as the number of criteria on each level, are quite significant in the implementation of AHP. For this reason, the structure of the present research is relatively simple, with data present of two levels (the 'criteria' and the 'sub-criteria'). The groups of criteria selected with the sub-criteria of each group of criteria are presented below per couple in the form of the final questionnaire.

A questionnaire consisting of a total number of 34 questions (comparisons per couples) was developed. The questionnaire simply asks for a pairwise comparison of the 'sub-criteria' for the 4 major criteria categories which is the major input of the AHP analysis.

It should be mentioned that the structure of the questionnaire was such that, the respondents were asked to compare each sub-criterion included in the Criterion, with the remaining sub-criteria of the Criterion. Therefore there is no comparison of all the sub-criteria separately with the remaining belonging to other criteria. This was done for purposes of abridging the number of the questions. Despite all these, with the Expert Choice $^{\mathrm{TM}}$ software that was used, the gravity coefficients were calculated without the aid of such a comparison.

\subsection{Field Research and Data Analysis}

The questionnaire was addressed to bank executives with major job duty the provision of investment consulting. The sample consisted of 52 questionnaires from the following bank branches situated in the metropolitan Athens area: National Bank, Agricultural Bank, Eurobank, Alpha Bank, Emporiki Bank, Piraeus Bank and Probank. Another 60 questionnaires were completed by bank executives from the same bank branches located within the greater Peloponnese region with the addition of the Bank of Peloponnese. The study is conducted the first two months of 2013.

As discussed above, the answers to the questionnaire were the used in the AHP method to analyze the data and determine the rank of each alternative criterion on a numerical scale. AHP aims to identify the experts' opinions by using questionnaires in which the criteria and sub-criteria of each criterion are prioritized in couples.
These can determine the impact of the criteria influencing the selection of investment products in a portfolio.

\section{RESULTS}

This section presents the results derived by using the Expert Choice ${ }^{\mathrm{TM}}$ software. The degree of participation of each criterion and sub-criterion, which depicts its gravity for the achievement of the objective, reveals the existing differences and ranks the decision factors.

Figure 2 and 3 present the Local (L) and Global (G) priorities based on our goal. Global priorities (G) are obtained for nodes by applying each node's Local priority (L) and its parent's Global priority $(G)$. The global priorities for each alternative are then summed to yield overall or synthesized priorities. The preferred alternative is the one with the highest priority.

The ranking of factors and their significance presented in Table 1 is also illustrated in Fig. 4. As described, "financial situation of potential investors" is the major drive for portfolio investment. Based on the results of the data analysis, "financial situation of potential investors," is indeed a very important factor, ranked as the top criterion for both the Metropolitan city Investor (MI) and for the Regional Investor (RI).

In summation, the criteria, "financial situation of potential investors," "the type of investor," "the type of investment," "characteristics of potential investors," receive the same ranking, from both the MI and the RI, with some difference in their significance (Table 2). Regarding the differences in significance among the criteria, the results (gravities) from the AHP analysis of the research with the questionnaires clearly demonstrates the greatest significance for the factor concerning the "financial situation of potential investors," with 0.453 of the RI over the significance of 0.378 for the MI. Contrary to that, all the rest of the criteria including "the type of investor," and "the type of investment," depict the greatest significance for the MI compared to that of the RI, 0.253 to 0.219 and 0.231 to 0.195 , respectively (illustrated in Fig. 4). The significance of the "characteristics of potential investors," is relatively the same, 0.139 for the MI compared to 0.134 for the RI.

The synthesis with respect to our goal for both the MI and the RI was also calculated by the Expert Choice ${ }^{\mathrm{TM}}$ software and is shown in Fig. 5. Note that synthesis is the process of weighting and combining priorities throughout the model to yield the final result after judgments have been made. 
Diakomihalis Mihail et al. / American Journal of Economics and Business Administration 5 (4): 120-128, 2013

Table 1. The Criteria of investors from athens and from Peloponnese and their ranking by significance

\begin{tabular}{|c|c|c|c|c|c|}
\hline \multirow[b]{2}{*}{ Criteria } & \multicolumn{2}{|c|}{ Athens } & \multicolumn{3}{|c|}{ Peloponnese } \\
\hline & Rank & Significance & Rank & Significance & Difference \\
\hline Characteristics of potential investor & 4 & 0,139 & 4 & 0,134 & +0.005 \\
\hline Financial situation of potential investor & 1 & 0,378 & 1 & 0,453 & -0.075 \\
\hline Type of investor & 2 & 0,253 & 2 & 0,219 & +0.034 \\
\hline Type of investment & 3 & 0,231 & 3 & 0,195 & +0.036 \\
\hline
\end{tabular}

Table 2. The total of sub-criteria of investors from athens and from Peloponnese and their ranking by significance

\begin{tabular}{|c|c|c|c|c|c|}
\hline \multirow[b]{2}{*}{ Criteria } & \multicolumn{2}{|c|}{ Athens } & \multicolumn{2}{|c|}{ Peloponnese } & \multirow[b]{2}{*}{ Difference } \\
\hline & Rank & Significance & Rank & Significance & \\
\hline Income & 1 & 0.140 & 2 & 0.127 & +0.013 \\
\hline Forecast for future income & 2 & 0.100 & 3 & 0.092 & +0.008 \\
\hline Risk level & 3 & 0.093 & 10 & 0.051 & +0.042 \\
\hline Tolerance of losses during 1 year in recession period & 4 & 0.081 & 7 & 0.054 & +0.027 \\
\hline Possetion of assets & 5 & 0.079 & 1 & 0.165 & -0.086 \\
\hline Investment experience & 6 & 0.072 & 8 & 0.053 & +0.019 \\
\hline Level of return and fluctuation & 7 & 0.064 & 11 & 0.050 & +0.014 \\
\hline Psychological reaction in negative fluctuations & 8 & 0.063 & 9 & 0.052 & +0.011 \\
\hline Profession/occupation & 9 & 0.059 & 4 & 0.069 & -0.010 \\
\hline Time of investment return & 10 & 0.046 & 6 & 0.057 & -0.011 \\
\hline Education & 11 & 0.041 & 12 & 0.045 & -0.004 \\
\hline Length of time holding investment & 12 & 0.037 & 5 & 0.061 & -0.024 \\
\hline Familiarity with technology & 13 & 0.035 & 16 & 0.018 & +0.015 \\
\hline Age & 14 & 0.028 & 13 & 0.037 & -0.009 \\
\hline Aim of investment & 15 & 0.028 & 14 & 0.036 & -0.008 \\
\hline Marital status & 16 & 0.026 & 15 & 0.021 & +0.005 \\
\hline Gender & 17 & 0.008 & 17 & 0.012 & -0.004 \\
\hline
\end{tabular}

\begin{tabular}{|c|}
\hline Goal: Criteria detemining Portfolio Investment \\
\hline 口 1) CHARACTERISTICS OF POTENTIAL INVESTOR (L: 0,139, G:0,139) \\
\hline 口 GENDEP.(L: 0,058, G:0,008) \\
\hline$\square \mathrm{AGE}(\mathrm{L}: 0,205, \mathrm{G}, 0,028)$ \\
\hline 口 EDUCATION (L: 0,297, G:0,041) \\
\hline 口 MAPITALSTATUS (L: 0, 190, G:0,026) \\
\hline 口 FAMILIAPITY WITH TECHNOLOGY (L:0,249, G:0,035) \\
\hline 口 2) FINANCIAL STTUATION OF POTENTIAL INVESTOR (L: 0,378, G:0,378) \\
\hline aPP.OFESSION (L:0, 156, G:0,059) \\
\hline$\square \operatorname{INCOME}(\mathrm{L}: 0,370, \mathrm{G} 0,140)$ \\
\hline 口 POSSETION OF ASSETS (L: 0,209, G0,079) \\
\hline 口FOPECAST FOP.FUTUPE INCOME (INDIVIDUALOP. FAMLLY) (L:0,265, G:0,100) \\
\hline ๑3) TYPE OF INVESTOR (L: $0,253, \mathrm{G}: 0,253)$ \\
\hline 口LENGTH F TIME HOLDING INVESTMENTS (L: 0,147, G:0,037) \\
\hline 口INVESTMENT EXPEPIENCE (L: 0,284, G0,072) \\
\hline 口PSYCHOLOGICALPEACTION IN NEGATIVE FLUCTUATIONS (L: 0,249, G.0,063) \\
\hline 口 TOLEP.ANCE OF LOSSES DUPING 1 YEAP. IN PECESSION PEPIOD (L: 0,320, G:0,081) \\
\hline 口4) TYPE OF INVESTMENT (L: 0,231, G:0,231) \\
\hline 口AIM OF INVESTMENT (L: $0,121, \mathrm{G} 0,028)$ \\
\hline 口 LEVELOF PETUPN AND FLUCTUATION (L: 0,276, G:0,064) \\
\hline 口PISK LEVEL(L: 0,405, G.0,039) \\
\hline 口TIME OF PETUP.N (L: 0, 199, G:0,046) \\
\hline
\end{tabular}

Fig. 2. Tree view of criteria and sub-criteria for investors from Athens 


\begin{tabular}{|c|}
\hline 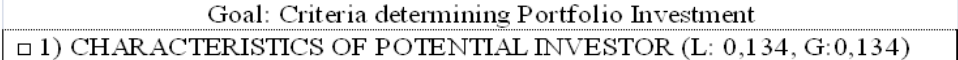 \\
\hline $\begin{array}{c}\text { 口1) CHARACTERISTICS OF POTENTIAL INVESTC } \\
\square \text { GENDER (L: } 0,089, \text { G:0,012) }\end{array}$ \\
\hline \\
\hline ㅁ AGE (L: $0,274, \mathrm{G}: \mathrm{C}$ \\
\hline EDUCATION (L: $0,339, \mathrm{G}: 0,045)$ \\
\hline 口 MARITAL STATUS (L: $0,161, \mathrm{G}: 0,021)$ \\
\hline 口 FAMIIIARITY WITH TECHNOLOGY (L: $0,138, \mathrm{G}: 0,018)$ \\
\hline 2) FINANCIAL SITUATION OF POTENTIAL INVESTOR (L: $0,453, \mathrm{G}: 0,453$ ) \\
\hline$\square$ PROFESSION (L: 0,152, G:0,069) \\
\hline$\square$ INCOME (L: 0,281, G:0,127) \\
\hline$\square$ POSSETION OF ASSETS (L: 0,364, G:0,165) \\
\hline 口FORECAST FOR FUTURE INCOME (INDIVIDUAL OR FAMILY) (L \\
\hline 口3) TYPE OF INVESTOR (L: 0,219, G:0,219) \\
\hline 口LENGTH OF TIME HOLDING INVESTMENTS (L: 0,277, G:0,061) \\
\hline$\square$ INVESTMENT EXPERIENCE (L: 0,241, G:0,053) \\
\hline$\square$ PSYCHOLOGICAL REACTION IN NEGATIVE FLUCTUATIONS (L: \\
\hline $\begin{array}{l}\text { व TOLERANCE OF LOSSES DURING } 1 \text { YEAR IN RECESSION } \\
\text { PERIOD (L: } 0,246, \text { G:0,054) }\end{array}$ \\
\hline 口4) TYPE OF INVESTMENT (L: 0,195, G:0,195) \\
\hline$\square$ AIM OF INVESTMENT (L: $0,185, \mathrm{G}$ \\
\hline 口 LEVEL OF RETURN AND FLUCTUATION (L: $0,259, \mathrm{G}: 0,050)$ \\
\hline$\square$ RISK LEVEL (L: 0,261, G:0,051) \\
\hline 口 TIME OF RETURN (L: 0,295, G:0,057) \\
\hline
\end{tabular}

Fig. 3. Tree view of criteria and sub-criteria for investors from Peloponnese

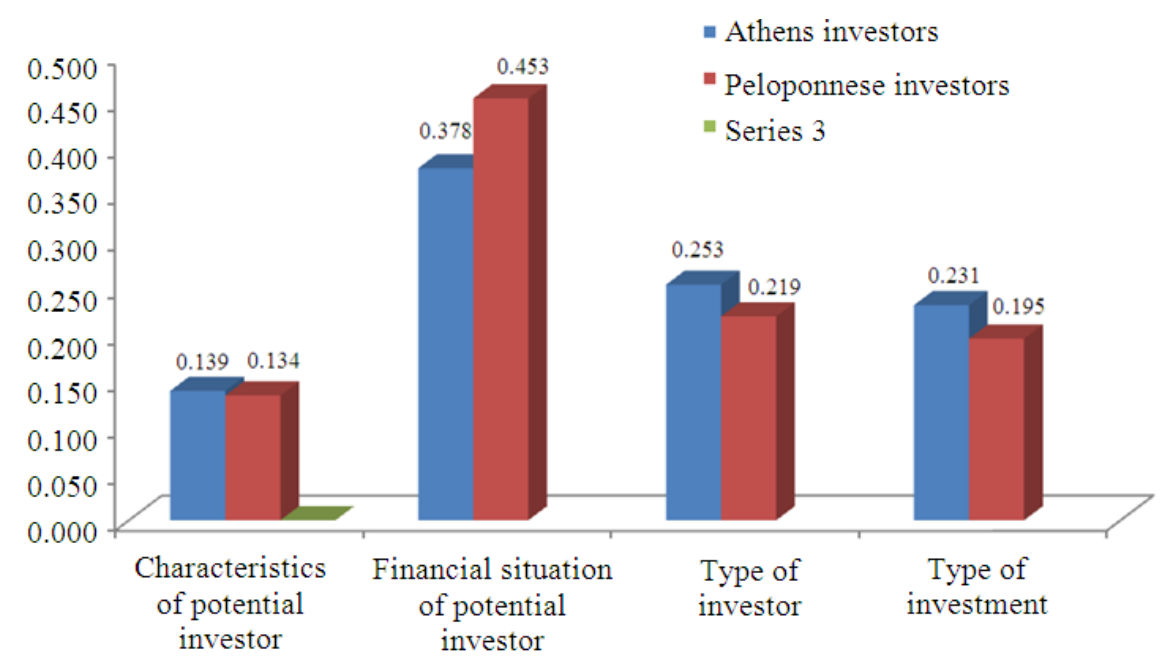

Fig. 4. Criteria differences between investors from Athens and from Peloponnese

The significance differences of the sub-criteria between the MI and the RI are illustrated in Fig. 5. For comparison purposes, we selected all the subcriteria to present the difference in significance between MI and RI.

The five most significant sub-criteria for MI ranked by gravity are "income" $(0.140)$, "forecast for future income" (0.100), "risk level" (0.093), "tolerance of losses during one year of recession period" $(0.081)$ and "possession of assets" (0.079). Respectively for the RI are "possession of assets" (0.165), "income" $(0.127)$, "forecast for future income" (0.092), "profession/occupation" (0.069) and "length of time holding investment" (0.061).

The significance differences of the sub-criteria between the MI and the RI are illustrated in Fig. 5. For comparison purposes, we selected all the sub-criteria to present the difference in significance between MI and RI. 


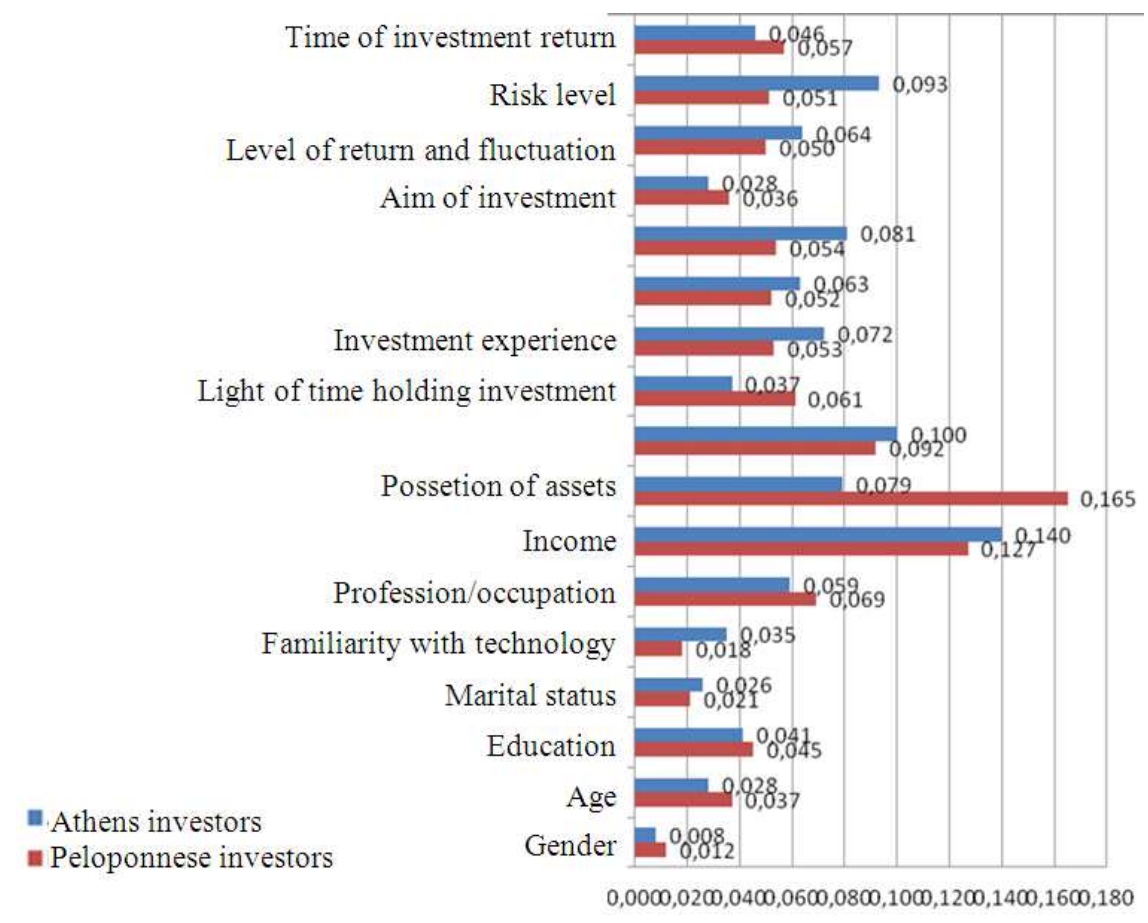

Fig. 5. Sub-criteria differences between investors from Athens and from Peloponnese

The five most significant sub-criteria for MI ranked by gravity are "income" $(0.140)$, "forecast for future income" (0.100), "risk level" (0.093), "tolerance of losses during one year of recession period" (0.081) and "possession of assets" (0.079). Respectively for the RI are "possession of assets" (0.165), "income" (0.127), "forecast for future income" (0.092), "profession/occupation" (0.069) and "length of time holding investment" (0.061).

According to significance comparison (Table 2 and Fig. 5), the highest difference is located in the "possession of assets," which is almost double (109\%) the significance for RI compared to MI. Such difference is expected due to the ranking difference of the specific sub-criterion, which is 1 st for RI and 5th for MI (-0.086).

The second highest difference occurred in the "risk level" sub-criteria, by $82 \%$ higher significance for MI compared to RI. The difference is justified by the ranking gap of the sub-criterion, which is 3rd for MI and 10 th for RI $(+0.042)$.

The third highest difference occurred in the "tolerance of losses during 1 year of recession period," by $50 \%$ higher significance for MI compared to RI $(+0.027)$. The decline of the difference is justified by the ranking mitigation of the sub-criterion, which is 4th for MI and 7th for RI. The following highest difference concerns the "length of time holding investment," with $65 \%$ higher significance for RI to MI. The ranking difference is quite high, placing 5 th for RI and 12th for MI (-0.024).

The fifth highest difference concerns the "investment experience," with $36 \%$ higher significance for MI to RI. The ranking difference is only two positions, 6th for MI and 8 th for RI $(+0.019)$.

The five smallest differences in significance are depicted in the sub-criteria ranked at 11 th to 17 th position. Their values are less than 0,010 . These subcriteria and their significance difference are "gender" ($0.004)$, "education" (-0.004), "marital status" (+0.005), "aim of investment" (-0.008) and "age" (-0.009).

\section{DISCUSSION}

This study dealt with the complex issue of portfolio investment and, specifically, the factors that determine the selection of financial investment products. An investment portfolio synthesis is characterized by high complexity. According to the literature, the success of a 
portfolio is determined by the expected return and the investment risk, while the suitable combination of different investment products decreases the unsystematic risk. The decisions involved in conducting an investment portfolio synthesis are affected by a number of different factors and determined by those factors and how they relate to the specific investor. The geographic origin or the residence of the investor is decisive in investment choices. Therefore, this work tries to identify and rank the key decision parameters for investors residing in a metropolitan city versus investors residing in a region or province.

To this end, the methodology presented in section 3 was applied. At the beginning, a set of key factors was identified based on the literature review and discussions with experts ((Diakomihalis and Stefanidaki, 2012). Based on that, a questionnaire was developed and addressed to two sample groups, one from the metropolitan city of Athens and another from regional Greece, specifically the Peloponnese.

The responses were analyzed with specialized software using the Analytic Hierarchy Process (AHP) to determine the key decision factors regarding an optimal portfolio investment. The AHP method, which is analyzed in section 2, is the most widely used MultiCriteria Decision-Making Method (MCDM).

Regarding the criteria, the analysis revealed that the factor of "financial situation of potential investors" is the top drive for portfolio investment for both Metropolitan City Investors and Regional Investors, but quite more significantly for Regional Investors. In addition, the three other criteria are relatively significant in the same order among Metropolitan City Investors and Regional Investors. "Type of investor" and "type of investment" are somewhat more significant for MI, while "characteristics of potential investors" is of equal significance for both groups.

\section{CONCLUSION}

From the above it might be concluded that the fact that Regional Investors more significantly evaluate the criterion of "financial situation of potential investors," is a sign of feeling less secure than the investors from the Metropolitan City. The minor significance of the criteria "type of investor" and "type of investment" by the Metropolitan City Investors compared to the Regional Investors indicates that $\mathrm{MI}$ are more familiar and experienced with evaluating issues concerning their private savings investments.

A clear difference between the two groups of investors concerns the sub-criteria. The highest difference, for the RI, concerns the sub-criterion "possession of assets," confirms the lower level of security of the RI. The next most significant differences, for the MI, "risk level" and "tolerance of losses during one year of recession period," could be attributed to the more demographically widespread professionalism of the investors of MI compared to the RI. The fourth highest difference, for the RI, concerning the sub-criterion "length of time holding investment," supports lower level of professionalism that influenced their approach to their investment choices compared to the MI. The subcriterion "investment experience" is evaluated more significantly for the MI.

The sub-criteria with less notable difference in significance between Metropolitan City investors and regional investors are the last five in significance for both groups: "Gender," "education," "marital status," "aim of investment," and "age."

General conclusions stemming from the comparative study of these two groups of investors and based on the judgments of banking executives specializing in investment consulting, are the following concept correlations characterizing each group of investors compared to the other.

The Metropolitan City Investors seem to be more experienced, more dispassionate, more patient and conservative than the Regional Investors. Furthermore, the MIs are more tolerant, provident and informed. The Regional Investors can be perceived as more enthusiastic and interested in taking risks than the MIs. However, they also appear to feel less secure when it comes to investing.

The research aimed to identify and evaluate the factors that influence the decisions of portfolio investors and to contribute to the knowledge of the field.

In this context, we make distinct comparisons among the decision criteria of investors from the metropolitan city and from a more rural region respectively. Even if this research had not been conducted before, we believe that the results cannot be generalized due to the small number of participants. Another limitation of the study is that the Metropolitan City Investors sample was selected only from Athens and the Regional Investors sample was selected only from the Peloponnese.

Future research should address these limitations and include investors from other metropolitan cities (e.g., Thessaloniki), other regions of Greece (e.g., Ionian, Aegean, Thrace, Macedonia,) and, eventually, from other countries. 


\section{REFERENCES}

Agwuegbo, S.O.N., A.P. Adewole and A.N. Maduegbuna, 2010. A random walk model for stock market prices. J. Math. Stat., 6: 342-346. DOI: 10.3844/jmssp.2010.342.346

Burton, G.M., 2003. The efficient market hypothesis and its critics. J. Econom. Perspectives, 17: 59-82. DOI: $10.1257 / 089533003321164958$

CI, 2011. What is a portfolio. Greek.

Chen, I., 2005. Will financial analysts mistake stocks of good companies for good stocks? Evidence from taiwan stock market. Am. J. Applied Sci., 2: 383386. DOI: 10.3844 /ajassp.2005.383.386

Cooper, R.G. and S.J. Edjett, 2001. Portfolio Management for New Products: Picking the Winners. 1st Edn., Working Paper.

Diakomihalis, M. and E. Stefanidaki, 2012. Cruise ship supply chain: A field study on outsourcing decisions. Int. J. Decision Sci. Risk Manage., 3: 369-383.

Haugen, R.A., 2001. Modern Investment Theory. 1st Edn., Prentice Hall International, Upper Saddle River, ISBN-10: 0130304735, pp: 656.

Markowitz, H., 1952. Portfolio selection. J. Finance, 7: 77-91. DOI: 10.1111/j.1540-6261.1952.tb01525.x

Parlinska, M. and I. Petrovska, 2011. AHP model for investor's decision making process. Proceedings of the 4th International Conference Entrepreneurship in the Global Environment: New Challenges in the Post-Crisis Era" T.E.I. of Epirus, Oct. 13-14. Preveza, Greece, pp: 134-140.
Rachmawati, R.N., Sufon and W. Budiharto, 2014. European call option application in incomplete market-analysis and development. J. Comput. Sci., 10: 157-168. DOI: $10.3844 /$ jcssp.2014.157.168

Saaty, T.L., 1977. A scaling method for priorities in hierarchical structures. J. Math. Psychol., 15: 234281. DOI: 10.1016/0022-2496(77)90033-5

Saaty, T.L., 1980a. Multicriteria Decision Making: The Analytic Hierarchy Process. 1st Edn., Mc GrawHill, New York.

Saaty, T.L., 1980b. The Analytic Hierarchy Process. 2st Edn., McGraw-Hill Co., New York, ISBN-10: 0070543712, pp: 287.

Saaty, T.L., 1999. The Seven Pillars of the Analytic Hierarchy Process. 1st Edn., ISAHP: Kobe Japan

Saaty, T.L., 2005. Theory and Applications of the Analytic Network Process: Decision Making with Benefits, Opportunities, Costs and Risks. 3rd Edn., Rws Publications, ISBN-10: 1888603062, pp: 352.

Strong, R.A., 1993. Porfolio Construction. 1st Edn., Management and Protection.

Yusuff, R.M., K.P. Yee and M.S.J. Hashmi, 2001. A preliminary study on the potential use of the Analytical Hierarchical Process (AHP) to predict Advanced Manufacturing Technology (AMT) implementation. Robotics Comput. Integrated Manuf., 17: 421-427. DOI: 10.1016/S07365845(01)00016-3 